\title{
MINERALOGY OF ULTRAMAFIC DIKES FROM THE SARFARTOQ, SISIMIUT AND MANIITSOQ AREAS, WEST GREENLAND: KIMBERLITES OR MELNOITES?
}

\author{
Mitchell, Roger $\mathrm{H}^{1}{ }^{1}$, Scott Smith, Barbara H. ${ }^{2}$, \& Larsen, Lotte M. ${ }^{3}$
}

1. Department of Geology, Lakehead University, 955 Oliver Rd., Thunder Bay, Ontario, Canada P7B 5E1
2. Scott-Smith Petrology, 2555 Edgemount Blvd., North Vancouver, British Columbia, Canada V7R 2M9
3. Geological Survey of Denmark and Greenland (GEUS), Thoravej 8, DK-2400, Copenhagen, Denmark

Ultramafic dikes and sheets occur in several areas of West Greenland (Larsen \& Rex 1992). The regions of Sisimiut (Holsteinsborg), Sarfartoq and Maniitsoq-Sukkertoppen contain three distinct groups of $600 \mathrm{Ma}$ old ultramafic dikes. The contemporaneous Sarfartoq carbonatite complex lacks ultramafic rocks but is the focus of a cone sheet of some of the Sarfartoq ultramafic dikes. All of the rocks described in this work have been previously been classified as kimberlites, in part because they have gross petrographic similarities to some archetypal kimberlites and host upper mantle-derived garnet lherzolite xenoliths (Larsen \& Ronsbo 1993, Scott 1981). Diamonds have been reported both historically and recently from these areas of ultramafic dikes. Currently, central and south-west West Greenland are the focus of intensive diamond exploration. This study includes some of the newly discovered dikes and boulders from the Maniitsoq area which have recently been shown to contain diamonds and subcalcic $\mathrm{Cr}$-pyrope (G10 garnet).

Classification of these rocks on a purely petrographic basis is difficult. On the one hand they have some similarities with kimberlite i.e. the presence of two generations of olivine plus groundmass spinel, phlogopite and perovskite, whereas on the other, on a modal basis, they might also be described using lamprophyre terminology as aillikite or alnoite. Some examples, poor in mica, could even be termed olivine spinel carbonatite. Consequently, the rocks may be regarded as falling in the region of petrographic convergence between the extreme variants of melnoite and kimberlite recognized by Scott (1995). From an economic viewpoint correct classification is critical as identification as melnoite would normally result in the province being given low exploration priority with respect to its diamond potential. Terminological problems may be resolved by resorting to mineralogical-genetic classifications of the type advocated by Mitchell (1995). This type of classification attempts to determine the magma type from which rocks are formed and permits discrimination between petrographically similar, but genetically distinct, rocks which might on a purely petrographic basis be inappropriately named.

The dike rocks exhibit an extremely wide variation in their xenolith/xenocryst content and modal mineralogy, resulting in part from the pronounced flow differentiation of their undoubtedly very low viscosity carbonate-rich parental magmas. Despite the modal variation, all of the rocks are mineralogically similar and composed essentially of primary olivine, spinel, phlogopite and carbonate. The principal petrographic differences are seen in the accessory and oxide mineralogy. Each group is of slightly different petrographic character, e.g. the Sarfartoq rocks are characterised by the presence of perovskite whereas this mineral appears to be absent in the Maniitsoq suite. Despite these differences, in terms of their overall mineralogy (see below) all of the rocks must be considered as being cogenetic. 
All of the dikes contain macrocrysts of rounded fresh-to-partially serpentinized magnesian olivine. These are associated with microxenoliths of therzolite and dunite and are in part undoubtedly derived by fragmentation of these rocks. Crystals lacking strain cannot be unambiguously classified. Some macrocrysts containing inclusions of Mg-ilmenite may be cognate. Others contain small droplets of Fe-Ni sulphides and may have inclusions of chromite. Macrocrysts may be unzoned, normally (e.g. $\mathrm{mg \#}=90.8-84.5)$ or reversely- $(\mathrm{mg \#}=77.9-83.7)$ zoned. Total range in mg\# is $91.8-77.8$; commonest is $90-84$. In general these olivines are richer in Fe than those kimberlite. A mixed population of normal and reversed zoned crystals is unlike that found in kimberlite. Phenocrysts of euhedral-to-subhedral olivine are common and in some examples are the only primary silicate phase.

Microphenocrystal phlogopite occurs as anhedral-to-rectangular plates. Many crystals have thin red rims of tetraferriphlogopite. The cores of the crystals are pale yellow and very weakly pleochroic and show no optical zonation. All are $\mathrm{Cr}$-poor $\left(<0.05\right.$ wt. $\left.\% \mathrm{Cr}_{2} \mathrm{O}_{3}\right)$ with low $\mathrm{BaO}$ contents $(0.1-1.1$ wt.\%). $\mathrm{TiO}_{2}$ ranges from $1-3.5 \mathrm{wt} \%, \mathrm{Al}_{2} \mathrm{O}_{3}$ from 11.5 - $17.0 \mathrm{wt} . \%$, and $\mathrm{FeO}$ from $6.5-8.5 \mathrm{wt} . \%$ $\mathrm{FeO}_{\mathrm{T}}$. $\mathrm{NiO}$ is $<0.1 \mathrm{wt} . \%$. The evolutionary trend is from high $\mathrm{Al}$ and $\mathrm{Ti}$ to low $\mathrm{Al}$, lower $\mathrm{Ti}$ and higher Fe. Tetraferriphlogopite rims are low in $\mathrm{TiO}_{2}(<1.0 \mathrm{wt} . \%)$ and $\mathrm{Al}_{2} \mathrm{O}_{3}(<2.5 \mathrm{wt} . \%)$ and have very high $\mathrm{FeO}_{\mathrm{T}}(15.0-18.5$ wt.\%) at high $\mathrm{MgO}$ contents. $\mathrm{Ba}$ and $\mathrm{Cr}$ contents are low ( $<0.3$ wt.\%). The overall composition i.e. alumina enrichment, and evolutionary trends are unlike groundmass micas in kimberlite and members of the phlogopite-kinoshitalite series are absent.

Ilmenite is found as: anhedral inclusions in olivine macrocrysts; mantled macro/microcrysts; and euhedral groundmass laths. Inclusions in macrocrysts have a limited compositional range 10-12 wt.\% $\mathrm{MgO}$ 2.7-5.0 wt. $\% \mathrm{Cr}_{2} \mathrm{O}_{3}$, and $<1 \mathrm{wt} . \% \mathrm{Al}_{2} \mathrm{O}_{3}, \mathrm{MnO}$, and $\mathrm{Nb}_{2} \mathrm{O}_{5}$, and are similar to spinel-mantled ilmenite in the same rock. All rocks are characterised by irregular macrocrysts and microcrysts of $\mathrm{Mg}$ ilmenite mantled by zoned $\mathrm{Cr}$-poor $\mathrm{Mg}$-Ti-magnetite. The latter are compositionally identical to discrete primary groundmass spinels. Individual samples contain $\mathrm{Mg}$-ilmenite of distinct compositional ranges. Large macrocrysts may have $\mathrm{MgO}$-poor (10-12 wt.\%) cores and are zoned towards $\mathrm{MgO}-$ rich margins (19-23 wt.\%). Their is no correlation of $\mathrm{Mg}$ with $\mathrm{Cr}$ content and the most magnesian ilmenites may be poor ( $<1.0 \mathrm{wt} . \%)$ or rich (3-5 wt.\%) in $\mathrm{Cr}_{2} \mathrm{O}_{3}$. The crystals may have rutile, $\mathrm{PbS}$ and $\mathrm{ThO}_{2}$ inclusions but not spinel. Macrocrysts are interpreted to be high pressure cognate phases. Primary euhedral ilmenite in the groundmass contains 1-20 wt.\% $\mathrm{MgO}$ and may be enriched in $\mathrm{Mn}$ and $\mathrm{Nb}$ relative to spinel-mantled ilmenite. In some instances quench-like aggregates of very fine grained cryptocrystalline prisms of $\mathrm{Mg}$-free ilmenite occur in dolomite.

Spinel forms mantles on ilmenite and occurs as discrete euhedral-to-subhedral crystals in the groundmass. Atoll-textured spinels only very rarely present. The spinels are typically $\mathrm{Cr}$-poor relative to kimberlite spinels and primarily members of the $\mathrm{MgAl}_{2} \mathrm{O}_{4}-\mathrm{Fe}_{2} \mathrm{TiO}_{4}-\mathrm{Fe}_{3} \mathrm{O}_{4}$ series. Many crystals contain anhedral-to-rounded discrete inclusions of $\mathrm{Cr}$-poor $(\mathrm{Mg}, \mathrm{Fe}) \mathrm{Al}_{2} \mathrm{O}_{4}$ or subhedral cores of $\mathrm{Al}$ rich chromite. Many crystals have outer mantles of Ti-magnetite or magnetite. Individual spinel crystals may be weakly-to-strongly zoned and particular dikes differ in the extent of zoning. The evolutionary trend follows that of trend 2 of Mitchell (1995) and is thus unlike that of spinels found in kimberlite.

Some rocks contain primary $\mathrm{Cr}$-poor diopside. At Sisimiut these contain 1-4 wt.\% $\mathrm{TiO}_{2}$ and 1-6 wt. $\% \mathrm{Al}_{2} \mathrm{O}_{3}$. At Sarfartoq they contain 1-2 wt.\% $\mathrm{TiO}_{2}$ and 1-2.5 wt.\% $\mathrm{Al}_{2} \mathrm{O}_{3}$. The compositions 
suggest that they, in common with mica and spinel, crystallised from a relatively aluminous magma. Perovskite occurs as subhedral-to-rounded crystals and as a part of reaction assemblages around ilmenite macrocrysts. All are relatively pure $\mathrm{CaTiO}_{3}$ perovskite. Not all dikes contain perovskite and in some instances perovskite has been replaced by an intimate intergrowth of $\mathrm{Mg}$-free ilmenite, anatase and kassite. Apatite forms subhedral, commonly resorbed prisms, and irregular groundmass plates; most has crystallised subsequent to spinel and contemporaneously with groundmass carbonates. The apatite is poor in $\mathrm{Sr}$ and REE.

The mesostasis of the dikes is composed primarily of calcite plus dolomite in an emulsion or irregular intergrowth texture. Some dikes contain patches of serpentine. Other minerals present are: $(\mathrm{Ca}, \mathrm{Ti})-$ $\mathrm{Zr}$-oxide (zirconolite?) , (Ca, Ti)-Nb-oxide, $\mathrm{ZrO}_{2}$ (baddeleyite), $\mathrm{TiO}_{2}$ (rutile and/or anatase), kassite, thorite, strontiobarite, barite, celestite, strontianite, $\operatorname{Sr}(\mathrm{REE})$-carbonate (ancylite?) galena, chalcopyrite, pyrite, $\mathrm{Ni}$-pyrite, and djerfisherite.

The West Greenland ultramafic dikes differ markedly in their mineralogy from archetypal kimberlites in that they contain primary high $\mathrm{Al}$-mica, Al-diopside, compositional trend 2 spinels (Mitchell 1995), and are enriched in late stage $\mathrm{Sr}-\mathrm{Ba}$ minerals. They lack members of the phlogopite-kinoshitalite series and primary mica reacts in some instances with magma to form tetraferriphlogopite. Perovskite is low in abundance compared with bona fide kimberlites. It is concluded on the basis of this mineralogical-genetic classification that these rocks are NOT kimberlites, and that their mineralogical characteristics suggest derivation from an aluminous ultrabasic carbonated magma. It is suggested this magma is of melilitite composition as such magmas elsewhere evolve to produce similar ultramafic lamprophyres and form rocks containing mantle-derived ultramafic xenoliths. Against this hypothesis is the observation that melilitites and related rocks have not yet been found in this region. However, this may merely reflect a sampling bias as carbonate-rich rocks are resistant to weathering. Silicate rocks may have been deeply-weathered and not observed in reconnaissance work.

On the basis of the above it is concluded that the Sisimiut, Sarfartoq and Maniitsoq fields are not kimberlites but form a part of a previously unrecognized $200 \times 100 \mathrm{~km}$ province of alkaline magmatism in West Greenland. The dikes may be termed melnoites or ultramafic lamprophyres (sensu lato), and as such may represent a carbonate-rich extreme variety of the melilitite clan. The presence of subcalcic Cr-pyrope and diamond in Maniitsoq dikes but apparently not in the Sisimiut or Sarfartoq rocks cannot as yet be explained. Although all dikes must have passed through the Archean cratonic crust at depth, only the Maniitsoq magmas appear to sampled and disaggregated, a diamond-bearing horizon. This province is now recognized as one of the few bona fide provinces of diamond-bearing melnoites or ultramafic lamprophyres; consequently it may contain economic melnoite!

\section{References}

Larsen, L.M., and Rex, D.C. 1992, A review of the 2500 Ma span of alkaline-ultramafic, potassic and cabonatitic magmatism in West Greenland, Lithos, 28, p. 367-402.

Larsen, L.M., and Rønsbo, J., 1993, Conditions of origin of kimberlites in West Greenland: new evidence from the Sarfartoq and Sukkertoppen regions, Rpt. Grønl. Geol. Unders. 159, p.115-120. Mitchell, R.H. 1995, Kimberlites, Orangeites and Related Rocks, Plenum Press, New York. Scott, B.H., 1981 Kimberlite and lamproite dykes from Holsteinsburg, West Greenland, Medd. Grønland Geosci., 4, 24pp.

Scott Smith, B.H., 1995, Petrology and Diamonds, Explor. Mining Geol.,4, p.127-140. 